\title{
Impacts of regional integration and maritime transport on trade: with special reference to RCEP
}

\author{
Shu-Man Chang \\ Department of Aviation and Maritime Transportation Management, \\ Chang Juang Christian University, Tainan, Taiwan \\ Yo-Yi Huang \\ Institute of Applied Economics, National Taiwan Ocean University, \\ Keelung, Taiwan, and \\ Kuo-Chung Shang and Wei-Tzu Chiang \\ Department of Transportation Science, National Taiwan Ocean University, \\ Keelung, Taiwan
}

\section{Maritime transport on trade}

Received 8 March 2020 Revised 21 March 2020 24 March 2020 Accepted 25 March 2020

\begin{abstract}
Purpose - The proposed Regional Comprehensive Economic Partnership (RCEP) will become a large trade agreement in Asia, which has brought together the ten members of Association of Southeast Asian Nations (ASEAN) and five of the neighbors' countries. Under the trend of globalization, the progress of the transportation industry and regional integration will increase the volume of trade, therefore maritime performance is intrinsically linked to trade. In fact, few studies have examined regional integration in the context of seaborne. This paper aims to use the cluster analysis and Poisson quasi-maximum likelihood (PQML) gravity model to investigate the trading bloc phenomenon and relation between trade and marine transportation.
\end{abstract}

Design/methodology/approach - In this paper, hierarchical clustering analysis and tree diagrams are used to identify functional areas characterized by bilateral trade intensity and bilateral liner shipping connectivity indices. Regional reorganizations that have occurred within Asian countries were studied. This study illustrates that these trading blocs have a positive impact on trade when maritime transport, production and trading networks have developed between regions. A gravity model was constructed using worldwide trade data for 2007, 2010 and 2015. The study considered free trade agreement (FTA)/common market (CM) of EU, RCEP and North American Free Trade Agreement (NAFTA) as regional dummies and designed a real trade bloc induction variable. In addition, the study did not use the commonly adopted ordinary least squares (OLS) estimation but used the PQML method to estimate the gravity equation to overcome the problem of a large number of zero trade observations. Preliminary results show that regional integration cannot guarantee the establishment of intraregional trade but depends on the stage of economic development and regional industrial characteristics.

Findings - The major findings are summarized as follows. Both liner shipping connectivity and logistics performance have significant advantages with positive coefficients in each regression results. The creation of intraregional trade is not guaranteed, depending on the characteristics of the trade and the stage of economic development of the region. For RCEP, the effect created by intra-regional trade is better than the EU. Instead,

(C) Pacific Star Group Education Foundation. Licensed re-use rights only.

This paper has been presented at the 9th International Forum on Shipping, Ports and Airports, held at Hong Kong Polytechnic University. The authors are grateful to the two anonymous referees and participants at the conferences for useful comments on the earlier version of this paper. Financial support from the Ministry of Science and Technology (MOST 106-2410-H-019-001 and MOST 1062914-I-019-005-A1) is acknowledged. Any remaining errors are our responsibility.

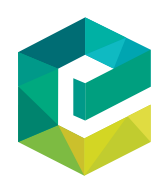

Maritime Business Review Vol. 5 No. 2,2020 pp. $143-158$ Emerald Publishing Limited 2397-3757 DOI 10.1108/MABR-03-2020-0013 
MABR

5,2

the "nominal" intra-RCEP trade was significantly below the "real" trading blocs. For RCEP, the effect created by intra-regional trade is better than that of the EU. Instead, "nominal" intra-RCEP trade is much lower than "real" trading blocs. The real trading bloc between East Asia and Taiwan clearly exists, and the bloc phenomenon is becoming more and more significant. This result shows that Taiwan's trade flow with East Asia is higher than the normal level relationship implied by its corresponding economic and geographical conditions.

Originality/value - This paper focuses on new empirical work done for this study is on the potential impact on trade. Earlier studies that have discussed and/or provided estimates of the benefits to the RCEP plan from improved transport and supply chain connectivity are cited. Marine transportation performance inherently links to economies of commerce. Few studies have examined regional integration in the context of maritime transportation, which reflects the lack of a mix of trade economists and maritime logistics research in the existing literature. This paper attempts to investigate the trading bloc phenomenon formed by regional integration (such as RCEP) and the relation between trade and marine transportation. With the official entry into force of the RCEP in 2020, it will promote increased trade and demand for logistics and maritime transport services in East Asia.

Keywords Trade, RCEP, Liner shipping connectivity index, Logistics performance index, Poisson quasi-maximum likelihood

Paper type Research paper

\section{Introduction}

In the past decade, we witnessed a surge in regional trade agreements (hereafter RTAs), while Taiwan has mainly been on the sideline [1]. The center of global development has long since shifted from Europe and the USA to Asia. East Asia's economy is gradually moving toward integration.

The formation of the Association of Southeast Asian Nations (ASEAN) Economic Community (AEC) in 2015 was an important milestone in the process of ASEAN integration [2]. One very ambitious initiative is the Regional Comprehensive Economic Partnership (hereafter RCEP), which includes ten member states of the ASEAN, Singapore, Brunei, Malaysia, Indonesia, Thailand, Philippines, Vietnam, Cambodia, Lao, Myanmar and six other nations along the West Pacific Rim: Japan, South Korea, China, India, Australia and New Zealand. However, after negotiating for about seven years, India decided to pull out of RCEP since November 2019. As shown in Table 1, the 15 RCEP countries which represent more than 2.18 billion people, 22.47 billion gross domestic product ([GDP] about $40 \%$ of global GDP) and $99.7 \%$ of trade of GDP.

Members in the RCEP are closely economically connected to Taiwan. For instance, in 2017 exports to RCEP members consist of 57\% of Taiwan's total exports. In addition, from 2003 to 2015 Taiwan's outward FDI to RCEP members represent 80\% of Taiwan's total outward FDI.

The performances of maritime transportation within RCEP are shown in Table 2. On the whole, China, Hong Kong, Singapore, Korea and Malaysia have the greatest performances within RCEP. In terms of liner shipping connectivity index (hereafter LSCI), the average performance of RCEP countries is about 53.35 [3]. China, Hong Kong, Singapore, Korea and Malaysia are ranked within the top five countries with the LSCI indices. Of those RCEP countries, the average performance of logistics performance index (hereafter LPI) is about 3.2025. The top three countries with higher LPI index are Singapore, Hong Kong and Japan. In term of quality of port infrastructure, the rankings came in the order of Singapore and Hong Kong. From Table 2, one can see that China, Singapore, Korea, Malaysia, Hong Kong and have the highest performances, world top ten, in container handled.

Logistics originally focused on the analysis of the supply chain to optimize the flow of components necessary for production processes. The literature includes EU logistics 


\begin{tabular}{lccccr}
\hline Country & $\begin{array}{c}\text { Population } \\
\text { (thousand) }\end{array}$ & $\begin{array}{c}\text { GDP } \\
\text { (billion) }\end{array}$ & $\begin{array}{c}\text { GNI per } \\
\text { capita (US\$) }\end{array}$ & $\begin{array}{c}\text { Trade of } \\
\text { GDP }(\%)\end{array}$ & $\begin{array}{c}\text { Area } \\
\left(1000 \mathrm{~km}^{2}\right)\end{array}$ \\
\hline Singapore & $5,61.23$ & 338 & $64,581.9$ & 317.8 & 0.717 \\
Brunei & 423 & 9.39 & 29,600 & 67.57 & 5.77 \\
Malaysia & 31,624 & 318.9 & $11,373.2$ & 133.2 & 328.55 \\
Thailand & $69,037.5$ & 455 & $7,273.6$ & 122.5 & 510.89 \\
Indonesia & $263,991.4$ & 1,015 & 11,880 & 39.36 & $1,811.57$ \\
Philippines & 104,918 & 313.6 & 10030 & 71.9 & 298.17 \\
Vietnam & 95,540 & 223.1 & 2,160 & 200.3 & 310.07 \\
Lao PDR & 6851.4 & 16.8 & $2,542.5$ & 51 & 230.8 \\
Cambodia & $16,005.4$ & 22.1 & 1,230 & 124.8 & 176.52 \\
Myanmar & $53,37.06$ & 66.7 & 1,210 & 47.8 & 653.52 \\
China & $1,386,395$ & 12143.4 & $9,770.8$ & 38.15 & 9,597 \\
Korea & 51,466 & 1530.7 & $31,362.8$ & 80.8 & 97.48 \\
Japan & 126,785 & 4859.9 & 43,490 & 34.6 & 364.56 \\
New Zealand & 4,596 & 173.8 & $41,945.3$ & 54.2 & 263.31 \\
Australia & 24,601 & 1330.1 & 48,280 & 67.6 & $7,682.3$ \\
Subtotal & $2,182,389.99$ & $22,469.1$ & $21,115.34$ (average) & 96.77 (average) & $25,304.417$ \\
Taiwan & 23,555 & 608.1 & 26,376 & 102 & 36.197
\end{tabular}

Maritime
transport on
trade

Sources: World Bank (WDI 2018) and http://asean.org; Taiwan Statistical Data Book (2018)

Table 1.

Economic profile of RCEP members and Taiwan (2017)

\begin{tabular}{|c|c|c|c|c|c|c|c|c|c|}
\hline County & Index & $\begin{array}{l}\text { LPI (2015) } \\
\text { Ranking }\end{array}$ & $\begin{array}{l}\text { LSCI (2018) } \\
\text { Index }\end{array}$ & Ranking & $\begin{array}{l}\text { Port } \\
\text { Index }\end{array}$ & Ranking & $\begin{array}{c}\text { Container port traffic } \\
\text { TEU }\end{array}$ & Ranking & \\
\hline Singapore & 4.07 & 6 & 110.83 & 2 & 6.66 & 2 & $36,600,000$ & 3 & \\
\hline Hong Kong & 3.95 & 9 & 93.54 & 5 & 6.35 & 5 & $19,641,000$ & 9 & \\
\hline Japan & 3.94 & 10 & 71.05 & 14 & 5.4 & 22 & $22,433,824$ & 6 & \\
\hline Australia & 3.8 & 18 & 32.02 & 47 & 4.99 & 35 & $7,524,343$ & 24 & \\
\hline Korea & 3.69 & 25 & 102.29 & 3 & 5.23 & 27 & $28,945,400$ & 4 & \\
\hline China & 3.6 & 29 & 151.30 & 1 & 4.55 & 54 & $225,828,900$ & 1 & \\
\hline New Zealand & 3.52 & 35 & 22.92 & 67 & 5.47 & 20 & $3,328,700$ & 36 & \\
\hline Malaysia & 3.51 & 36 & 93.64 & 4 & 5.57 & 17 & $24,956,000$ & 5 & \\
\hline Thailand & 3.34 & 46 & 45.06 & 36 & 4.49 & 57 & $11,185,200$ & 20 & \\
\hline Vietnam & 3.07 & 66 & 60.38 & 20 & 3.91 & 90 & $16,374,195$ & 14 & \\
\hline Indonesia & 3.03 & 67 & 26.98 & 56 & 3.81 & 99 & $12,853,000$ & 16 & \\
\hline Philippines & 2.93 & 72 & 18.27 & 71 & 3.22 & 135 & $8,637,520$ & 27 & \\
\hline Cambodia & 2.77 & 88 & 8.35 & 109 & 3.71 & 102 & 742,100 & 96 & \\
\hline Myanmar & 2.35 & 174 & 9.97 & 112 & 2.62 & 163 & $1,288,000$ & 97 & \\
\hline Lao & 2.23 & 184 & 2.37 & 129 & 2.18 & 170 & - & - & \\
\hline Brunei & 1.44 & 201 & 4.56 & 134 & - & - & 128,026 & 107 & Table 2. \\
\hline Average & 3.2025 & & 53.35 & & 4.26 & & $28,031,081$ & & \\
\hline Taiwan & 3.71 & 24 & 68.68 & 15 & - & - & $15,320,000$ & 11 & performance for \\
\hline $\begin{array}{l}\text { Note: The syr } \\
\text { Source: WDI }\end{array}$ & $\begin{array}{l}\text { mbol of } \\
\text { I and U. }\end{array}$ & $\begin{array}{l}\text { "-" represer } \\
\text { CTAD auth }\end{array}$ & $\begin{array}{l}\text { nts that the } \\
\text { lors' calcula }\end{array}$ & are no in & lices of $t$ & cou & n UNCTAI & & $\begin{array}{r}\text { RCEP members and } \\
\text { Taiwan }\end{array}$ \\
\hline
\end{tabular}

research. Vilko et al. (2011) linked logistics with growth and found that if the infrastructure is used in innovative ways, countries with insufficient infrastructure can develop, such as Estonia. Behar and Manner (2008) used LPI index to explore the factors which affect the relevance of logistics to bilateral trade. Similarly, but unlike other papers in the literature, 
MABR

5,2

Behar and Manner (2008) analyzed how logistics performance affected EU exports between 2005 and 2010 to identify possible progress on behalf of member states. They used LPI and its components will be used as proxy variables to represent trade facilitation, and various gravity equations will be estimated.

Abe and Wilson (2011) studied how port infrastructure affects trade and the role of transportation costs in driving import and export in the region. They found that port congestion has significantly increased the cost of transportation from the USA and Japan to East Asia [4]. Puertas et al. (2014) found that the improvement of logistics performance led to a significant increase in its export volume. The above literature on logistics and trade provides useful contributions to private groups and authorities responsible for developing trade and transport policies. It is worth mentioning that Lagoudis et al. (2019) used cluster analysis to assess the attractiveness of offshore clusters. They pointed out that the financial, human and infrastructure promote the appeal of maritime clusters. In addition, better institutional partnerships and government support can improve the performance of maritime clusters.

Therefore, this paper focuses on new empirical work done for this study is on the potential impact on trade. Earlier studies that have discussed and/or provided estimates of the benefits to the RCEP plan from improved transport and supply chain connectivity are cited. Marine transportation performance inherently links to economies of commerce. Few studies have examined regional integration in the context of maritime transportation, which reflects the lack of a mix of trade economists and maritime logistics research in the existing literature. This paper attempts to investigate the trading bloc phenomenon formed by regional integration (such as RCEP) and the relation between trade and marine transportation. With the official entry into force of the RCEP in 2020, it will promote increased trade and demand for logistics and maritime transport services in East Asia.

This paper is organized as follows. Section 2 provides the empirical methods and discusses data and variable. Section 3 summarizes findings and discussion, and Section 4 provides concluding remarks.

\section{Empirical method}

Theoretically, a trading bloc can be defined as a group of countries characterized by relatively higher intra-group trade than "normal" level. Thus, two empirical methods are sequentially conducted in the study. In the process, the bloc can be identified through hierarchical cluster analysis, and then the gravity model is used to verify whether the trading bloc exists. Furthermore, if a "real" trading bloc and/or "nominal" RTAs (such as EU, NAFTA, ASEAN even RCEP) do matter significantly in certain years, then we would like to use the gravity model to examine how the trade intensity within the group has changed over time. For a bloc of disintegrating over time, the intra-group trade intensity would be expected to be declining. Conversely, as more and more integrated groups emerge, we expect the intensity of trade within the group to become higher.

\subsection{Cluster analysis of bilateral trade intensities and liner shipping connectivity index}

Clustering is a frequently used concept in a variety of applications. Huang et al. (2006) used bilateral trade data as a measure of similarity. The result of using its grouping properties is called a trade bloc. The results of hierarchical cluster analysis of the intensity of bilateral trade (or liner shipping connectivity) are used to identify groups with clear trade linkage. According to Huang et al. (2006), $T_{i j}$ is represented as bilateral trade intensity, which is defined as the proportion of trade volume (or liner shipping connectivity) between country $i$ 
and $j$ occupying the world proportion of the volume of total trade (or liner shipping connectivity). It can be expressed as follows:

$$
T_{i j}=\frac{X_{i j}+X_{j i}}{\sum_{j} \sum_{i} X_{i j}}
$$

where $\mathrm{X}_{i j}$ represents the export value of a particular product from the country $i$ to $j$ and $\mathrm{X}_{j i}$ represents the import value of a particular product from the country $j$ to $i$. The reciprocal of $T_{i j}$ is $1 / T_{i j}$, which represents the "economic distance." The economic intuition is as follows: if the intensity of trade between countries is higher, the "economic distance" between countries is smaller. It is more reasonably considered to belong to the same cluster.

Next, countries are linked to "hierarchical clusters" based on density linking algorithms. That is, when each country represents its own cluster at the beginning, the distance is the economic distance represented by the inverse of the above-mentioned bilateral trade intensity. Economic distance is defined as the average distance of the closest elements in each cluster for clusters containing multiple elements. Finally, all countries can be linked together to determine the presence of a trading bloc. The resulting group often represents long chains, as shown in the tree diagram. It should be noted that the similarity of the groups depends only on their closest members.

The empirical bilateral trade data is from UN Comtrade database at 2007, 2010, and 2015 [5]. For 2007 and 2015, we included Taiwan in the RCEP countries and used volume of trade (VOT) shares for clustering. The tree diagrams in Figures 1 and 2 describe the bilateral trade and liner shipping connectivity, respectively. The results will be discussed in Section 3.1. It will be tested in econometrics to check whether the bloc's intra-group trade intensity has increased or decreased over the past decades.

Dendrogram of the Hierarchic Cluster in VOT (2007)

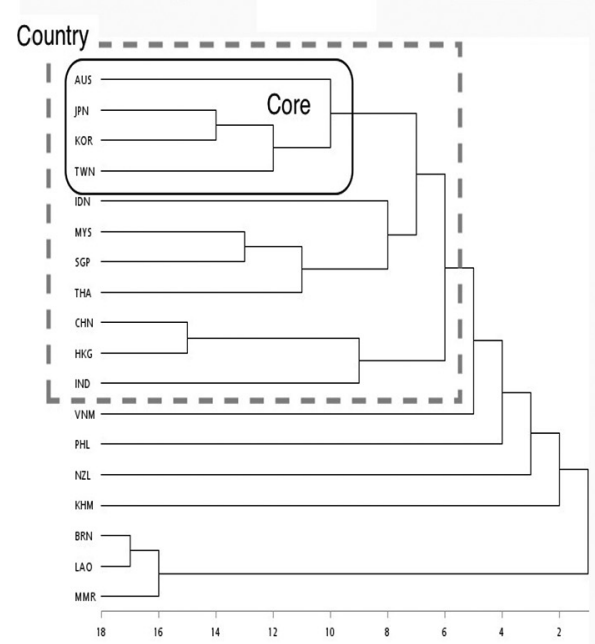

(a)

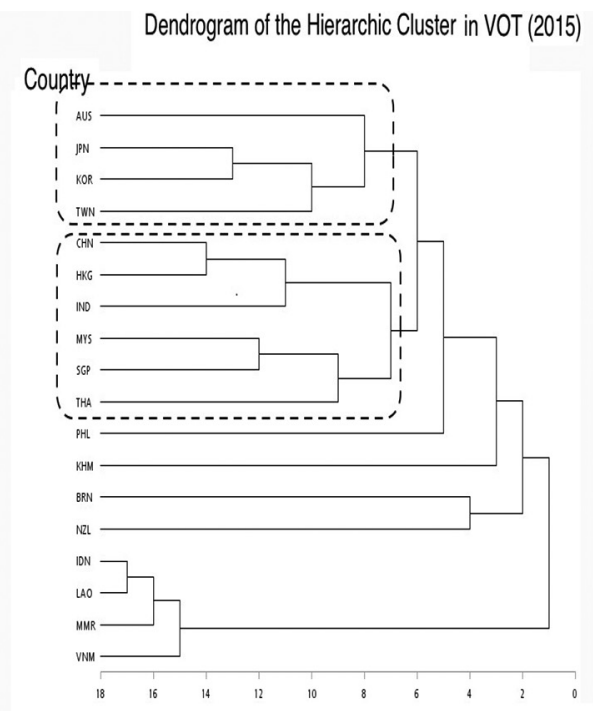

(b)
Figure 1. Cluster analysis in bilateral trade flows among RCEP and Taiwan 
MABR

5,2

\section{8}

\section{Figure 2.}

Cluster analysis in liner shipping market among RCEP and Taiwan

\section{Dendrogram of the Hierarchic Cluster in LSCI (2007)} Country

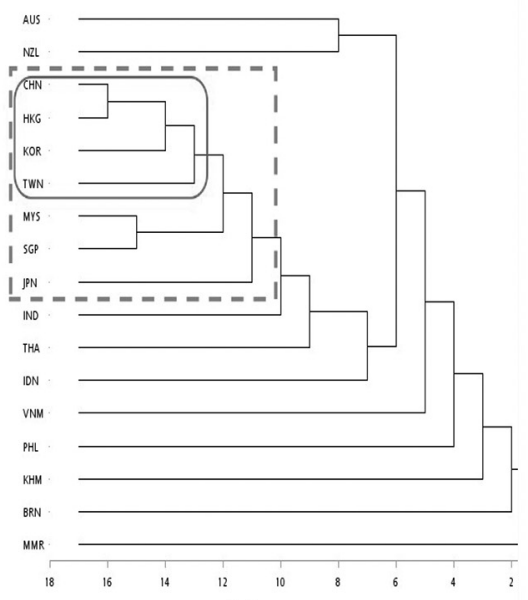

(a)

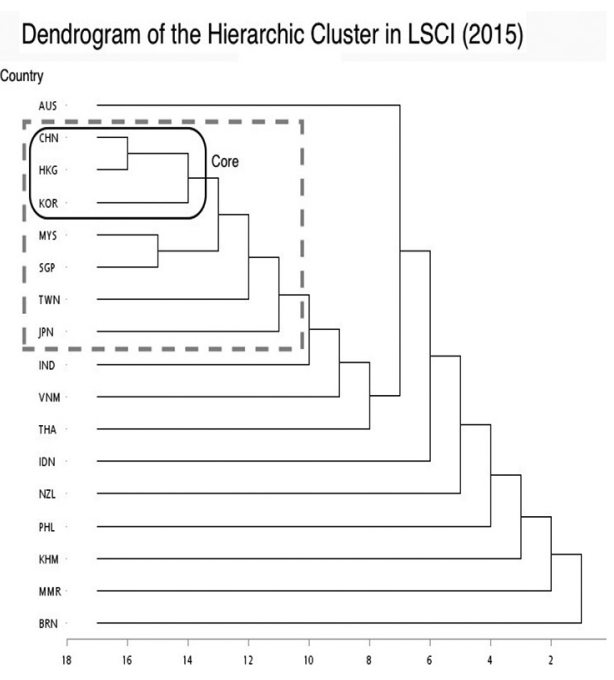

(b)

\subsection{Gravity model}

To test the impacts of maritime transportation and regional integration on trade, we will use a modified gravity equation method, which is an econometric model that is applied in international trade these last six decades. Gravity equations have been widely adopted in trade literature. Bilateral trade is explained from the determinants of the market size represented by GDP, population, national incomes and so on, geographical distance, as well as the intangible distances of language and culture, etc.

In this paper, we use a gravity model to investigate the effects of home market effects (hereafter HME) on maritime transport and regional integration, as demonstrated by Head and Ries (2001), Davis and Weinstein (1999), Crozet and Trionfetti (2008), Schumacher and Siliverstovs (2006), Huang and Huang (2011, 2016; Huang et al., 2017) and Chiang et al. (2017) [6].

In theory, if the advantage of the domestic market size is important, then we can observe that the impact of the GDP on the exporting country (variation of market size) is greater than the impact of the GDP on the importing country. If the RTA integration expands the market size and enhances the HME for member countries, then the HME coefficient of the relevant member countries should be larger.

Therefore, we must derive the gravity equation from the model. The basic gravity equation as following:

$$
\begin{aligned}
L V O T_{i j}= & \alpha+\beta_{1} L G D P_{i}+\beta_{2} L G D P_{j}+\beta_{3} L D I S T_{i j}+\beta_{4} L R P P P_{i j}+\beta_{5} R G N_{i j} \\
& +\beta_{6} C N T_{i j}+\mu_{i j}
\end{aligned}
$$

where let $\mathrm{LVOT}_{i j}=\log \left(\mathrm{VOT}_{i j}\right)$ be the logarithm of country $i$ 's trade to $j$ and apply to other variables. $\operatorname{LGDP}_{i}$ and $\mathrm{LGDP}_{j}$ are the logarithms of the output levels of $i$ and $j$; $\operatorname{LDIST}_{i j}$ is the bilateral distance, $\mathrm{LRPPP}_{i j}$ is the relative price levels of $i$ and $j . \mathrm{RGN}_{i j}$ is a dummy variable for regional integration. If country $i$ and $j$ both belong to the same RTA, then $\operatorname{RGN}_{i j}=1$, 
otherwise $\mathrm{RGN}_{i j}=0$. Furthermore, $\mathrm{CNT}_{i j}$ is a contiguity dummy, which is defined as follows: If both countries $i$ and $j$ belong to the same cluster (such as border, common language or cultural background), then $\mathrm{CNT}_{i j}=1$, otherwise $\mathrm{CNT}_{i j}=0$ and $\mu_{i j}$ is the error terms [7].

In theory, empirical support for the home market effect requires that the estimated coefficient of $\beta_{1}$ is significantly greater than the coefficient of $\beta_{2}$. In addition, the regional dummy variable captures the trade creation of the regional free trade area, that is, a positive $\beta_{5}$ indicates that trade creation exists.

We use some indices to measure country-specific maritime transport-related performance, such as LPI, LSCI and container traffic by countries (TEU) to measure the maritime transport-related performances in specific countries. The data of LSCI comes from UNCTAD and aims to capture the degree of connection between the economy and the global shipping network. The higher the index value, the easier it is to obtain a high-capacity and high-frequency global maritime freight system, thereby effectively participating in international trade. Therefore, the empirical formula for the one-year sample is as follows:

$$
\begin{aligned}
L V V O T_{i j}= & \alpha+\beta_{1} L G D P_{i}+\beta_{2} L G D P_{j}+\beta_{3} L D I S T_{i j}+\beta_{4} L R P P P_{i j}+\beta_{5} R G N_{i j}+\gamma_{1} L L S C I_{i} \\
& +\gamma_{2} L L S C I_{j}+\gamma_{3} L L P I_{i}+\gamma_{4} L L P I_{j}+\gamma_{5} L T E U_{i}+\gamma_{6} L T E U_{j}+\gamma_{7} \text { Border }_{i j} \\
& +\gamma_{8} \operatorname{ComLng}_{i j}+\mu_{i j}
\end{aligned}
$$

\subsection{Poisson quasi-maximum likelihood approach}

In fact, many zero observations are included in bilateral trade data. A common approach to the problem of taking the logarithm of zero is to replace the zero with a decimal number or simply discard the sample points. However, this method has been criticized for being biased. Recent influential papers such as Siliverstovs and Schumacher (2009), Silva and Tenreyro (2006, 2011) propose a new method, namely Poisson quasi-maximum likelihood (PQML), estimates to resolve the zero trade flows problem.

As it is impossible to define the logarithm of zero, we use the PQML approach instead of using the OLS method which is adopted to estimate the modified equation of (2). By equation (2),

$$
\begin{aligned}
E\left(V O T_{i j} \mid Z_{i j}\right)= & \exp \left[\alpha+\beta_{1} L G D P_{i}+\beta_{2} L G D P_{j}+\beta_{3} L D I S T_{i j}+\beta_{4} L R P P P_{i j}\right. \\
& +\beta_{5} R N_{i j}+\gamma_{1} L L S C I_{i}+\gamma_{2} L L S C I_{j}+\gamma_{3} L L P I_{i}+\gamma_{4} L L P I_{j}+\gamma_{5} L T E U_{i} \\
& \left.+\gamma_{6} L T E U_{j}+\gamma_{7} \text { Border }_{i j}+\gamma_{8} \operatorname{ComLng}_{i j}+\mu_{i j}\right]
\end{aligned}
$$

where $E\left(V O T_{i j} \mid Z_{i j}\right)=\left(1, G D P_{i}, G D P_{j}, D I S T_{i j}, \ldots\right)$ denotes the vector of all the explanatory variables, $Z_{i j}$ is measured the conditional variance $\mathrm{V}\left(\mathrm{VOT} \mid Z_{i j}\right)$; this is implied by equation (3) which imposes restrictions on the conditional moments of the dependent variable [8]. Therefore, the PQML process provides a feasible alternative to the traditional OLS estimation process. It is used to make consistent estimates of the parameters of the gravity model in the form of original multiplication. Another advantage of the PQML estimator is that it does not require problematic processing of the observed zero trade flows.

By equation (3), if $\beta_{1}>\beta_{2}$, we can expect the existence of the conventional HME. $\beta_{3}<$ 0 represents the negative impact of distance. $\beta_{5}>0$ expresses the positive trade creation under regional integration. $\beta_{4}>0$ and $\gamma_{i}>0$ reflect the positive impacts on relative price level effect and maritime transport effect. 
MABR

5,2

\section{0}

In summary, the main hypothesis to be studied in this paper are as follows:

- $\beta_{1}>\beta_{2}$, for the existence of traditional home market effect.

- $\quad \beta_{5}>0$, for or conventional trade creation effect under regional integration, such as EU, ASEAN, RCEP, etc. and

- $\gamma_{i}>0$, for an enhanced effect on trade under better performance in maritime transport or logistic. As mentioned above, regarding the theoretical prediction of transport effects, we expect the coefficients of LPI, and TEU to be positive. Theoretically, better efficiency of transport modes for the export and/or import country implies reducing transport time and lower trade costs. That is, the coefficient of transport variables is expected to be positive $\left(\gamma_{i}>0\right)$ in equation (3) to reflect a reduction in trade barriers (Table 3 ).

\subsection{Data}

Bilateral trade data retrieved from the Comtrade, UN. The years 2007, 2010 and 2015 are selected for analysis. We construct a sample of global trade in a specific year, corresponding to the number of countries/regions, in order of 193, 193, and 182 countries (Table 4). The observations in Table 5 are for the ten industry groups with the first digit of the Standard International Trade Classification code. We perform clustering through VOT shares in world trade and the liner shipping. The results are described by tree diagram of Figures 1 and 2 for the trading blocs and shipping blocs, respectively, and discussions will be made in Sections 3 and 4. A regional dummy will be established in the gravity equation based on each identified trading blocs. The bloc will be tested to check whether the intra-group trade intensity of the trading bloc is increasing or decreasing.

To estimate the gravity equation of (3), we need data on bilateral trade flows (VOT $i j$ ), the ratio of real exchange rate between country $i$ and country $j\left(\mathrm{PPP}_{j}\right)$, the geometrical distance between

\begin{tabular}{|c|c|c|}
\hline Variables & Description & Source \\
\hline $\operatorname{VOT}_{i j}$ & The volume of bilateral trade & Comtrade, UN \\
\hline $\mathrm{GDP}_{i}$ & The gross domestic product of export countries & WDI, World Bank \\
\hline $\mathrm{GDP}_{j}$ & The gross domestic product of import countries & WDI, World Bank \\
\hline $\mathrm{DIST}_{i j}$ & $\begin{array}{l}\text { The sum of maritime and inland routes between the ports of country } i \text { 's } \\
\text { and country } j \text { s is measured the transport distance }\end{array}$ & \\
\hline $\mathrm{RPPP}_{i j}$ & The ratio of real exchange rate between country $i$ and country $j$ & WDI, World Bank \\
\hline $\mathrm{LSCl}_{i}$ & The country $i^{\prime} s$ liner shipping connectivity index & UNCTAD \\
\hline $\mathrm{LPI}_{i}$ & The country $i^{\prime} s$ logistics performance index & WDI, World Bank \\
\hline $\mathrm{TEU}_{i}$ & The country $i^{\prime} s$ TEU of container handled & UNCTAD \\
\hline & Regional integration dummy. EU equals to 1 if the country is $\mathrm{EU}$ & \\
\hline NAFTA & $\begin{array}{l}\text { Regional integration dummy. NAFTA equals to } 1 \text { if the country is } \\
\text { Canada, Mexico and the USA }\end{array}$ & \\
\hline RCEP & $\begin{array}{l}\text { Regional integration dummy variable. RCEP equals to } 1 \text { if country is } \\
\text { ASEAN, Japan, Korea, New Zealand, China and Australia }\end{array}$ & \\
\hline $\mathrm{EA}_{\text {core }}$ & $\begin{array}{l}\text { Core trading bloc dummy variable in East Asia. } \text { EA }_{\text {core }} \text { equals to } 1 \text { if the } \\
\text { country belongs to the core of trading blocs in RCEP and Taiwan. See } \\
\text { Figure } 1(\text { a) and (b). }\end{array}$ & \\
\hline ComLng $_{i j}$ & $\begin{array}{l}\text { Dummy variable. ComLng }{ }_{i j} \text { equals to } 1 \text { if countries } i \text { and } j \text { have a } \\
\text { common language }\end{array}$ & \\
\hline Border $_{i j}$ & $\begin{array}{l}\text { Dummy variable. Border }{ }_{i j} \text { equals to } 1 \text { if countries } i \text { and } j \text { have a } \\
\text { common land border }\end{array}$ & \\
\hline
\end{tabular}

Table 3.

List of variables

$$
\text { common land border }
$$




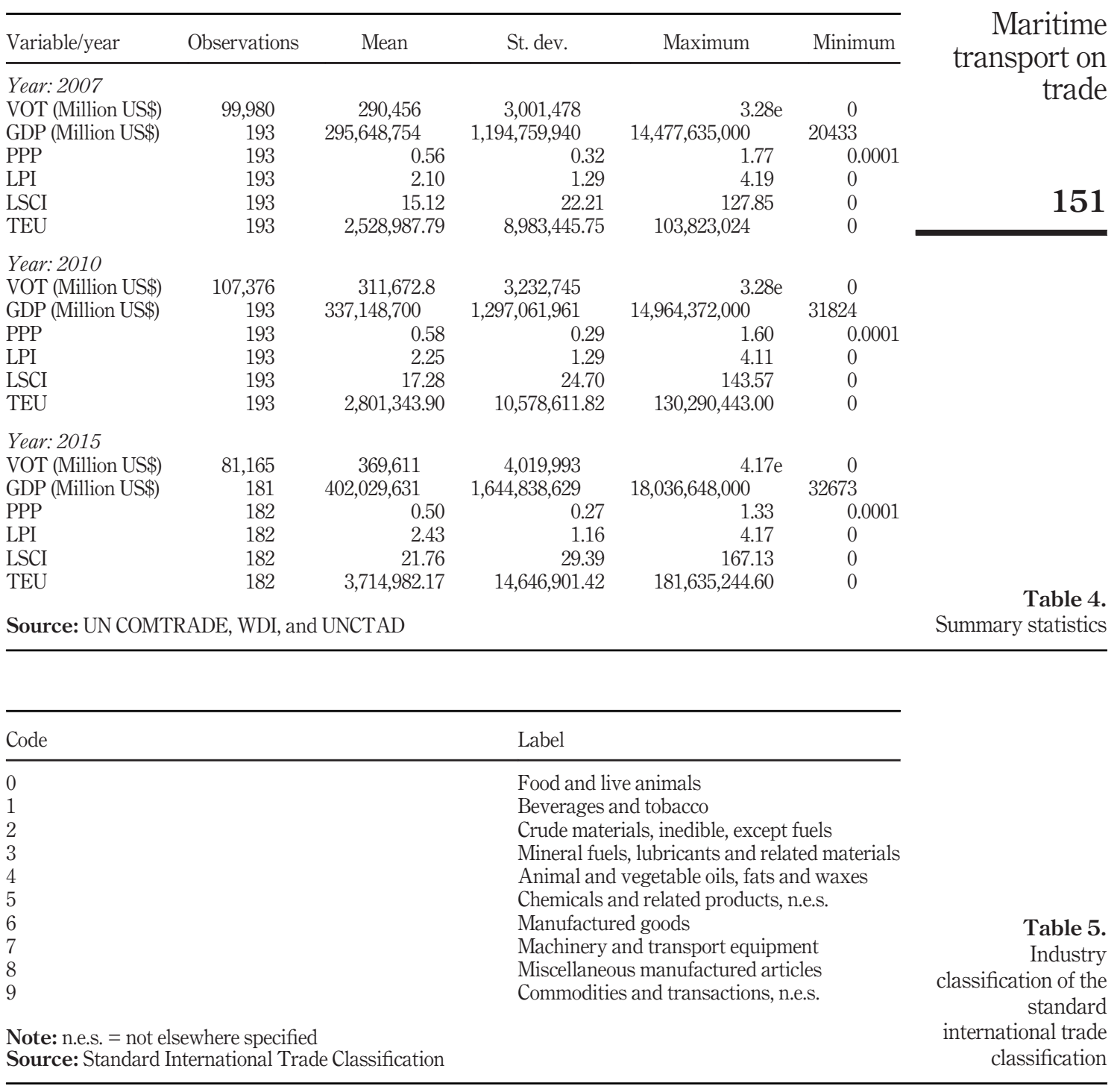

any pair of countries to represent the transport cost (DIST $i j)$ and the performance of maritime transport of each country [9]. Variables to be used in the regression is reported in Table 7.

\subsection{Cluster analysis}

2.5.1 Bilateral trade flows among regional comprehensive economic partnership and Taiwan. The tree diagrams in Figure 1(a) and (b) depict the results of hierarchical cluster analysis of bilateral trade flows (VOT) between RCEP and Taiwan in 2007 and 2015, respectively. In theory, the graph reveals the strength of transactions within a given cluster. 
MABR

5,2

If the cluster density is higher, intra-cluster trade flows will be more intensive. The results are interpreted using some level of density threshold, as shown by the dotted lines in each figure. There are two important characteristics of the trading bloc that can be identified.

2.5.1.1 Double blocs phenomenon of bilateral trade. Over the past few decades, two different trade groups can be identified. First, as shown in the result for 2007 [Figure 1(a)], we could easily pin down only one trading blocs in East Asia. The first four countries (Japan, South Korea, Taiwan and Australia) are relatively more integrated than the other countries and are therefore denoted the core of the group.

2.5.1.2 Rising China-Tiger cub economies bloc. Trade blocs seem to reflect geographical distribution to some extent. One country appears to be trading more with more closer countries. Although slight changes in the composition of countries and the intensity of intragroup trade can be observed in the Figure 1(b), a two-bloc pattern emerged in the 2015 results. In short, based on the strength of bilateral trade through cluster analysis, only one trading group in East Asia can be identified.

In 2015 , there were two group phenomena. The core countries were mainly composed of South Korea, Japan, Taiwan and Australia in East Asia. We can find that the core countries are gradually changing from East Asian countries to Japan-led countries, followed by Korea, Taiwan, China, Hong Kong, Indonesia, Singapore and Malaysia and other Asian countries.

Based on to create a regional dummy in which is mainly composed of countries in East Asia for each of the identified core trading blocs, hereafter called $\mathrm{EA}_{\text {core }}$ Bloc. The corresponding $\mathrm{EA}_{\text {core }}$ Bloc dummy is designed as follows: If the trading partners identified through cluster analysis (Japan, Korea, Hong Kong, Singapore, “Taiwan”, China, Malaysia,

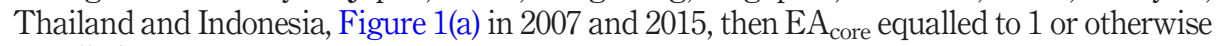
equalled to 0 .

2.5.2 Relations of liner shipping connectivity among regional comprehensive economic partnership and Taiwan. The hierarchical cluster analysis results of LSCI in 2007 and 2015 are described by the tree diagrams (tree diagrams) in Figure 2(a) and (b), respectively. As the 2007 results shown in the liner shipping market (Figure 2(a)), we could easily identify only one LSCI blocs in RCEP. The LSCI-blocs are mainly composed of countries including China, Hong Kong, South Korea, Taiwan, Japan, Malaysia and Singapore. The first four countries are relatively the core of the liner shipping group.

In addition, we make a rough comparison of the 2007 and 2015 tree plot results in Figure 2. It seems to indicate that the LSCI density within the North Asian bloc appears to have declined during this period. On the contrary, it can be seen that the liner shipping intensity of South Asian countries has increased.

However, even considering the geographical distance between countries and the market size (GDP per capita and GDP), intra-group trade is still relatively high.

\subsection{Empirical strategy}

To focus on the impact of regional trade over the past decade, we have selected 2007, 2010 and 2015 as observation windows. Strategically, we perform PQML gravity regression by specific year and analyze the estimated results of RTA, HME and maritime transportation and whether there have been changes during this period. Four types of models were designed for analysis. Model (a) is the basic model and contains only the basic gravity variables, such as $\mathrm{LGDP}_{i}, \mathrm{LGDP}_{j}, \mathrm{LDIST}_{i j}$, Border $_{i j}$ and ComLng $_{i j}$.

In Models (b) and (c), we add seaborne transportation indices, LSCI, LPI and TEU. For example, $\mathrm{LLSCI}_{i}$ and $\mathrm{LLSCI}_{j}$ to capture liner shipping connectivity differences between trading partners. In theory, countries that perform better in maritime transport should be able to export more. Therefore, we expect the estimated coefficients of $\operatorname{LLSCI}_{i}$ and LLSCI $i$ 
be positive. We hope that $\left(\mathrm{LLSCI}_{i}-\mathrm{LLSCI}_{j}\right)$ has a positive coefficient and that the country is doing better in liner shipping.

Models (b) and (c) extend model (a) with two types of regional dummy variables. The first is a nominal RGN dummy, including NAFTA, EU and RCEP. According to the previous definition, if the import and export countries are members of the underlying RGN, the RGN dummy takes value 1 , otherwise value 0 .

The impact of RTA-induced market size effects is estimated by $\mathrm{RGN}_{k}$. The second type, $\mathrm{EA}_{\text {core }}$, is a variable designed according to the core trading-blocs between RCEP and Taiwan in Figure 1. We considered Taiwan in Asia; therefore, this variable $\mathrm{EA}_{\text {core }}$ was included in Taiwan. When the estimated coefficient $\left(\mathrm{EA}_{\text {core }}-\mathrm{RCEP}\right)$ is positive, the empirical results support the real trading-blocs induced effect.

\section{Empirical results}

Tables 6-8 report the regression result of the PQML gravity equation in 2007, 2010 and 2015. The results show the standard results of the coefficients in the gravity model, namely negative coefficients of distance and positive coefficients of GDP. From Tables 6 and 7, some important findings of regional blocs and maritime transport identified in cluster analysis can also be obtained.

Table 6 provides the estimated results of the PQML regression model in equation (3). Column 2 Model a) shows the results of the basic gravity model, and Columns 3 (Model b) with country-level measures of seaborne transportation and the real trading bloc among East Asia, EA $_{\text {core }}$. Columns 4 (Model c) present regional integrations, EU, NAFTA and RCEP. In addition to these normal results for standard gravity variables, such as GDP, and distance. We can easily find that all identified blocs have significant positive coefficients. In other words, the found EA trading blocs are supported by an empirical gravity equation under cluster analysis rather than the nominal RECP.

\begin{tabular}{|c|c|c|c|c|}
\hline Variable & Model (a) & Model (b) & Model (c) & \\
\hline $\mathrm{LGDP}_{i}$ & $0.707 * *(27.43)$ & $0.484^{* * *}(12.80)$ & $0.431 * *(10.77)$ & \\
\hline $\mathrm{LGDP}_{j}$ & $0.740 * *(23.58)$ & $0.495 * *(9.46)$ & $0.442 * *(8.15)$ & \\
\hline $\mathrm{LPPP}_{i j}$ & $-0.0641 * *(-2.11)$ & $-0.0466 *(-1.72)$ & $-0.0449 *(-1.70)$ & \\
\hline LDIST $_{i j}$ & $-0.622 * *(-27.29)$ & $-0.398^{* *}(-12.59)$ & $-0.443^{* *}(-12.13)$ & \\
\hline adjcent & & $0.818^{* *}(6.14)$ & $0.522 * *(4.60)$ & \\
\hline comlng & & $0.536^{* *}(4.99)$ & $0.424 * *(3.42)$ & \\
\hline $\mathrm{LLSCI}_{i}$ & & $0.301 * *(6.23)$ & $0.353 * *(6.24)$ & \\
\hline $\operatorname{LLSCI}_{j}$ & & $0.265^{* *}(6.21)$ & $0.307 * *(6.18)$ & \\
\hline $\mathrm{LLPI}_{i}$ & & $0.858^{* * *}(3.06)$ & $0.966^{* * *}(3.36)$ & \\
\hline $\mathrm{LLPI}_{j}$ & & $1.348 * *(5.20)$ & $1.474 * *(5.46)$ & \\
\hline $\mathrm{LTEU}_{i}$ & & $0.0318(1.28)$ & $0.0419(1.45)$ & \\
\hline $\mathrm{LTEU}_{j}$ & & $0.0516 * *(3.06)$ & $0.0654 * *(3.32)$ & \\
\hline RCEP & & & $0.532 * *(4.27)$ & \\
\hline $\mathrm{EA}_{\text {cpre }}$ & & $0.855 * *(7.90)$ & & \\
\hline $\mathrm{EU}$ & & & $0.0687(0.72)$ & \\
\hline NAFTA & & & $0.959 * *(3.64)$ & \\
\hline Intercept & $-14.15 * *(-11.38)$ & $-9.922^{* *}(-7.28)$ & $-7.721^{* *}(-5.30)$ & Table 6. \\
\hline Observations & 99980 & 99980 & 99980 & \\
\hline Pseudo $R^{2}$ & 0.57 & 0.63 & 0.63 & $\begin{array}{l}\text { Results of PQMLL } \\
\text { gravity equation in }\end{array}$ \\
\hline \multicolumn{4}{|c|}{$\begin{array}{l}\text { Note: The superscripts * and ** represent significant levels of } 5 \% \text { and } 1 \% \text {, respectively. The number in } \\
\text { parentheses is the } Z \text {-value in PQML gravity equation }\end{array}$} & $\begin{array}{l}2007 \text { dependent } \\
\text { variable: } \text { VOT }_{i j}\end{array}$ \\
\hline
\end{tabular}

Note: The superscripts * and $* *$ represent significant levels of $5 \%$ and $1 \%$, respectively. The number in parentheses is the $Z$-value in PQML gravity equation

Maritime
transport on
trade

153 


\section{MABR \\ 5,2}

154

\begin{tabular}{|c|c|c|c|}
\hline Variable & Model (a) & Model (b) & Model (c) \\
\hline $\mathrm{LGDP}_{i}$ & $0.729 * *(26.94)$ & $0.485^{* *}(12.23)$ & $0.440 * * *(10.32)$ \\
\hline $\mathrm{LGDP}_{j}$ & $0.732^{* *}(22.12)$ & $0.441 * *(7.91)$ & $0.394 * *(6.74)$ \\
\hline $\operatorname{LPPP}_{i j}$ & $-0.0471(-1.17)$ & $-0.0535(-1.42)$ & $-0.0484(-1.37)$ \\
\hline $\mathrm{LDIST}_{i j}$ & $-0.634 * *(-28.41)$ & $-0.384 * *(-12.15)$ & $-0.438 * *(-11.67)$ \\
\hline adjcent & & $0.825^{* *}(6.01)$ & $0.526 * *(4.43)$ \\
\hline comlng & & $0.469 * *(4.33)$ & $0.356^{* * *}(2.63)$ \\
\hline $\operatorname{LLSCI}_{i}$ & & $0.208 * *(4.08)$ & $0.235 * *(3.78)$ \\
\hline $\mathrm{LLSCI}_{j}$ & & $0.221^{* *}(5.04)$ & $0.245^{* * *}(4.61)$ \\
\hline $\mathrm{LLPI}_{i}$ & & $1.525 * *(4.82)$ & $1.632 * *(5.05)$ \\
\hline $\mathrm{LLPI}_{j}$ & & $1.694 * *(5.12)$ & $1.832^{* * *}(5.22)$ \\
\hline $\operatorname{LTEU}_{i}$ & & $0.0701 *(1.80)$ & $0.0932 *(1.87)$ \\
\hline $\mathrm{LTEU}_{j}$ & & $0.112 * *(3.31)$ & $0.139 * *$ (3.25) \\
\hline RCEP & & & $0.497 * *(3.68)$ \\
\hline $\mathrm{EA}_{\text {cpre }}$ & & $0.810 * *(6.82)$ & \\
\hline $\mathrm{EU}^{-}$ & & & $0.0349(0.39)$ \\
\hline NAFTA & & & $0.955 * *(3.48)$ \\
\hline Intercept & $-14.54 * *(-11.42)$ & $-11.25^{* *}(-8.93)$ & $-9.604 * *(-7.16)$ \\
\hline Observations & 107376 & 107376 & 107376 \\
\hline Pseudo $R^{2}$ & 0.55 & 0.62 & 0.63 \\
\hline
\end{tabular}

\section{Table 7.}

Results of PQML gravity equation in 2010 dependent variable: $\mathrm{VOT}_{i j}$

\begin{tabular}{|c|c|c|c|}
\hline Variable & Model (a) & Model (b) & Model (c) \\
\hline $\mathrm{LGDP}_{i}$ & 0.870 *** $(28.01)$ & $0.680 * *(18.10)$ & $0.640 * *(16.78)$ \\
\hline $\mathrm{LGDP}_{j}$ & $0.840 * *(24.09)$ & $0.654 * *(11.53)$ & $0.618 * *(11.04)$ \\
\hline $\mathrm{LPPP}_{i j}$ & $-0.0371(-1.29)$ & $-0.0267(-1.12)$ & $-0.0339(-1.08)$ \\
\hline $\mathrm{LDIST}_{i j}$ & $-0.666^{* *}(-21.61)$ & $-0.324 * *(-6.64)$ & $-0.397 * *(-8.49)$ \\
\hline adjcent & & $1.128 * *(5.75)$ & $0.699 * *(4.18)$ \\
\hline comlng & & $0.189(1.30)$ & $0.2(0.95)$ \\
\hline $\operatorname{LLSCI}_{i}$ & & $0.114 * *(2.40)$ & $0.127 * *(2.23)$ \\
\hline $\operatorname{LLSCI}_{j}$ & & $0.164^{* *}(3.65)$ & $0.186^{* *}(3.50)$ \\
\hline $\mathrm{LLPI}_{i}$ & & $1.344 * *(2.67)$ & $1.504 * *(2.94)$ \\
\hline $\mathrm{LLPI}_{j}$ & & $1.955^{* *}(4.55)$ & $2.055^{* *}(4.46)$ \\
\hline LTEU $_{i}$ & & $0.0514(1.49)$ & $0.0749 *(1.73)$ \\
\hline $\mathrm{LTEU}_{j}$ & & $0.0101(0.62)$ & $0.0237(1.28)$ \\
\hline RCEP & & & $0.633 * *(4.21)$ \\
\hline $\mathrm{EA}_{\text {cpre }}$ & & $0.806^{* *}(4.87)$ & \\
\hline $\mathrm{EU}^{\mathrm{H}}$ & & & $0.0763(0.68)$ \\
\hline NAFTA & & & $0.758 * *(2.10)$ \\
\hline Intercept & $-21.35^{* *}(-14.97)$ & $-20.92 * *(-14.12)$ & $-19.35^{* *}(-12.14)$ \\
\hline Observations & 81165 & 81165 & 81165 \\
\hline Pseudo $R^{2}$ & 0.66 & 0.66 & 0.67 \\
\hline \multicolumn{4}{|c|}{ Note: Reference to Table 6} \\
\hline
\end{tabular}

An interesting empirical result is the distance coefficient. Bilateral distance represents transaction costs, as explained when using the gravity model of trade. As shown in the Model (a) of Tables 6-8, the coefficients for LDIST are about the same among 2007 (-0.622), $2010(-0.634)$ and $2015(-0.666)$. When both Models (b) and (c) are used, the distance 
coefficients are about 0.4. In Model (b) and (c), these two coefficients are significantly different from the two groups. We could easily find from Model (c) that the coefficient for LDIST significantly declines from the 0.443 for 2007 to 0.397 for 2015 in absolute value.

\subsection{Logistics effect and maritime transportation effects}

Both the World Bank's LPI and LSCI from UNCTAD provide information on the trade competitiveness of countries in the maritime transport and logistics fields in different ways. The logistics efficiency and the mode of transportation and the capacity of the terminal directly affect the transportation cost. In the regression results of Tables 6-8, both the estimated values of LSCI and LPI have significant positive coefficients, however, TEU does not. In addition, a rough comparison of the estimated coefficients of LSCI between 2007, 2010 and 2015 seems to indicate that the maritime transport within $\mathrm{LSCI}_{i}$ and $\mathrm{LSCI}_{j}$ have declined during this period. In contrast, as shown in Tables 6-8, the estimated LPI-induced exporter trade coefficients increased during this period, namely 0.966 in 2007, 1.632 in 2010 and 1.504 in 2015.

In sum, we find that the very strong results of liner shipping are also very highly significant, with the expected sign and elasticity being higher than the TEU of the handled container. This means that better infrastructure corresponds to lower transportation costs, as well as efficiency and positive economic consequences. Specifically, more developed transportation systems are more reliable and can handle more movement, and therefore often have lower transportation costs.

\subsection{Regional integration effects vs trading blocs}

Based on a cluster analysis of bilateral trade intensity supplemented by a gravity equation, this paper studies the evolution of trading pattern in the normal regional integration and nominal trading bloc. The major findings are as follows.

First, for nominal regional integration, we find that the effects of intraregional trade creation (such as the NAFTA, EU and RCEP) are decreasing in terms of intra-bloc trade intensity (Model (c) in Tables 6-8). In contrast, the $\mathrm{EA}_{\text {core }}$ is more integrated in terms of intra-bloc trade intensity (Model (b) in Tables 6-8).

Another interesting piece of evidence is the test of the bloc dummy of $\mathrm{EA}_{\text {core }}$ in 2007. In addition to the existence of two-bloc phenomena in the bilateral trade flow, that is, two different trading blocs can be identified in the last decades. The first is called the core bloc, which is mainly composed of East Asian countries. In Figure 1(b), it is called the ChinaTiger Cub Economy and is mainly distributed in Southeast Asia. Another growing one, called China-Tiger Cub Economies, mostly around East-South Asia in Figure 1(b).

The corresponding results are reported in Model (b) and Model (c) of Tables 6-8. The bloc dummy contained in the gravity equation is $\mathrm{EA}_{\text {core }}$, which is Model (c). For RCEP, the effect of intra-regional trade creation is better than the $\mathrm{EU}$ in the bilateral trade intensity. Instead, the intra-RCEP trade was significantly below the trading blocs, $\mathrm{EA}_{\text {core }}$ in 2007, 2010 and even more so in 2015, indicating the bilateral completion position among RCEP members. We could easily find Model (c) from Tables 6-8 that the coefficient for the RCEP significantly decreases from the 0.532 for 2007 to 0.5 for 2010 but increase to 0.633 for 2015 . In contrast, the estimated coefficient for the bloc dummy of $\mathrm{EA}_{\text {core }}$ also decreases over the periods, that is, 0.855 for 2007 as shown in the Model (b) of Table 6, 0.81 for 2010, as shown in Table 7, and 0.806 for 2015 .

We also find that the estimated coefficient of $\left(\mathrm{EA}_{\text {core }}\right.$-RCEP) is positive, therefore, these results support the real trading bloc-induced effects. In other words, in terms of the strength of bilateral trade flows, Taiwan is already part of the East Asian Economic Area. The estimates 
MABR

5,2

of the normal trade model that East Asia trading bloc anticipates are supported by market economy conditions, mean that RCEP is becoming more important.

\section{Concluding remarks}

In this paper, we use hierarchical clustering analysis and tree diagrams to identify functional areas characterized by bilateral trade intensity and bilateral LSCIs. We have studied regional reorganizations that have occurred within Asian countries. We illustrate that these trading blocs have a positive impact on trade when maritime transport, production and trading networks have developed between regions. Our findings reveal profound changes in the trade orientation of East Asia from the North toward the South since 2007, especially, after the financial crisis and the role of the global supply chain in fostering a trading bloc. That is, the focus of global development has shifted from Europe and the USA to Asia. The economies of the East Asian region are also gradually moving toward integration.

We use the gravity model that has been commonly used on international trade to study the ex-post effect of trade agreements. A gravity model was constructed using worldwide trade data for 2007, 2010 and 2015. We considered FTA/CM of EU, RCEP and NAFTA as regional dummies and designed a real trade bloc induction variable. In addition, we did not use the commonly adopted OLS estimation but used the PQML method to estimate the gravity equation to overcome the problem of a large number of zero trade observations. Preliminary results show that regional integration cannot guarantee the establishment of intraregional trade but depends on the stage of economic development and regional industrial characteristics.

Our main findings are summarized as follows. First, all variables of liner shipping connectivity (LSCI), logistics performance (LPI) and volume of TEU of container handled (TEU) have significantly positive coefficients in the regression results. In other words, the maritime transportation matters for trade. Second, depending on the characteristics of the trade and the stage of economic development of the region, the intra-regional trade creation cannot be guaranteed. Third, for RCEP, the intra-regional trade creation effect is better than the EU. Instead, the "nominal" intra-RCEP trade was significantly below the "real" trading blocs in 2007, 2010 and 2015. The fact is that economies with a large number of pre-agreement trades are "natural" trading blocs, and their agreements may lead to more trade creation than trade diversion, as Frankel et al. (1995) found. Fourth, there is a real trading bloc between East Asia and Taiwan, and the bloc phenomenon becomes more and more significant especially in 2007 and after. This result indicates that trade flows within Taiwan and the East Asia are far above normal levels implied by their respective geographic and economic conditions relationships.

In general, these results indicate that these regional free trade agreements (such as the RCEP) will have a positive impact on trade after production, maritime transport and trade networks between members have been developed. Findings from our empirical results indicate that the current trade volumes are affected by past volumes of trade. Therefore, using the current trade volume, it is possible to predict the trade effect of the upcoming implementation of RCEP.

\section{Notes}

1. An RTA is a treaty between two or more countries that defines trade rules for all signatories and is a treaty.

2. ASEAN officially announced plans to form the ASEAN Community in 2020 at the 2003 summit meeting and then rescheduled to 2017 at the 2007 summit. Finally, the (AEC was formally established on December 31, 2015, 23 years after the establishment of the ASEAN free trade area (AFTA) in 1992. 
3. The LSCI records how countries are connected to the global transport network. It is calculated by the United Nations Conference on Trade and Development (UNCTAD) based on the five components of the maritime transport sector.

4. Abe and Wilson (2011) showed that reducing port congestion by $10 \%$ could reduce East Asia's transportation costs by as much as $3 \%$. This means a comprehensive reduction in tariffs of $0.3-0.5 \%$.

5. UN COMTRADE is the pseudonym for United Nations International trade statistics database. For details, see https://comtrade.un.org/

6. Krugman (1979) proposed that the HME in larger countries with a large domestic market advantage, in the industry with increasing returns to scale (IRTS), will exceed the proportion of global market share. For a discussion of empirical evidence and its references, see Feenstra $e t a l$. (2001), Feenstra (2002), Huang and Huang (2011, 2016, 2017).

7. See Huang and Huang $(2011,2016)$.

8. Equation (3) is the PQML estimator, which is consistent under the estimator's equidispersion assumption that the conditional mean $\mathrm{E}(V O T \mid Z)_{i j}$ given as $\exp \left(Z_{i j t}\right)$, see also Silva and Tenreyro (2006).

9. For simplicity, we consider only the bilateral distance to capture the effect of trade barrier. Other variables for trade barrier are the common language, colonial ties, FTA, etc.

\section{References}

Abe, K. and Wilson, J.S. (2011), "Investing in port infrastructure to lower trade costs in East Asia", Journal of East Asian Economic Integration, Vol. 15 No. 2.

Behar, A. and Manner, P. (2008), "Logistics and exports", African economics working paper series 293. CSAE WPS/2008-13, University of Oxford, Oxford.

Chiang, W.T., Huang, Y.Y., Shang, K.C. and Chang, S.M. (2017), "The impacts of Maritime transportation and regional integration on trade: with special reference to RCEP", 9th International Forum on Shipping, May 22-25, Hong Kong.

Crozet, M. and Trionfetti, F. (2008), "Trade costs and the home market", Journal of International Economics, Vol. 76 No. 2, pp. 309-321.

Davis, D.R. and Weinstein, D.E. (1999), "Economic geography and regional production structure: an empirical investigation", European Economic Review, Vol. 43 No. 2, pp. 379-407.

Feenstra, R. (2002), "Border effects and the gravity equation: consistent methods for estimation", Scottish Journal of Political Economy, Vol. 49 No. 5, pp. 491-506.

Feenstra, R., Markusen, J. and Rose, A. (2001), "Using the gravity equation to differentiate among alternative theories of trade", Canadian Journal of Economics/Revue Canadienne d Economique, Vol. 34 No. 2, pp. 430-447.

Frankel, J., Stein, E. and Wei, S.J. (1995), "Trading blocs and the Americas: the natural, the unnatural, and the super-natural", Journal of Development Economics, Vol. 47 No. 1, pp. 61-95. No.

Head, K. and Ries, J. (2001), "Increasing returns versus national product differentiation as an explanation for the pattern of US-Canada trade", American Economic Review, Vol. 91 No. 4, pp. 858-876.

Huang, Y.Y. and Huang, D.S. (2011), "Technology advantage and hme-market effects: an empirical investigation", Journal of Economic Integration, Vol. 26 No. 1, pp. 81-109.

Huang, Y.Y. and Huang, D.S. (2016), "Technology advantage and home-market effect: a Poisson Quasi maximum likelihood estimation", Taiwan Economic Forecast and Policy, Vol. 46 No. 2, pp. 1-40. 
MABR

5,2

Huang, D.S., Huang, Y.Y. and Sun, Y.C. (2006), "Production specialisation and trade blocs", Journal of Economic Integration, Vol. 21 No. 3, pp. 474-495.

Huang, Y.Y., Huang, D.S. and Tsay, C.L. (2017), “Country heterogeneity and home-market effects under FTA: with special reference to AEC", Asia-Pacific Research Forum, Vol. 64, pp. 1-21.

Krugman, P. (1979), "Increasing returns, monopolistic competition and international trade", Journal of International Economics, Vol. 9 No. 4, pp. 469-479.

Lagoudis, I., Madentzoglou, E.M., Theotokas, I.N. and Yip, T.L. (2019), "Maritime cluster attractiveness index", Maritime Business Review, Vol. 4 No. 2, pp. 169-189.

Puertas, R., Mart1, L. and Garcla, L. (2014), "Logistics performance and export competitiveness: European experience”, Empirica, Vol. 41, pp. 467-480.

Schumacher, D. and Siliverstovs, B. (2006), "Home-market and factor-endowment effects in a gravity approach", Review of World Economics, Vol. 142 No. 2, pp. 330-353.

Siliverstovs, B. and Schumacher, D. (2009), "Estimating gravity equation $s$ : to log or not to log?", Empirical Economics, Vol. 36 No. 3, pp. 645-669.

Silva, J.S. and Tenreyro, S. (2006), "The log of gravity", Review of Economics and Statistics, Vol. 88 No. 4, pp. 641-658.

Silva, J.S. and Tenreyro, S. (2011), "Further simulation evidence on the performance of the Poisson pseudo-maximum likelihood estimator", Economics Letters, Vol. 112 No. 2, pp. 220-222. No.

Vilko, J., Karandassov, B. and Myller, E. (2011), "Logistic infrastructure and its effects on economic development", China-USA Business Review, Vol. 10 No. 11, pp. 1152-1167.

\section{Further readings}

Davis, D. and Weinstein, D.E. (2003), "Market access, economic geography and comparative advantage: an empirical test", Journal of International Economic, Vol. 59 No. 1, pp. 1-23.

\section{Corresponding author}

Yo-Yi Huang can be contacted at: hyy@ntou.edu.tw

For instructions on how to order reprints of this article, please visit our website: 